\title{
Effect of Aqueous Extract of Giant Horsetail (Equisetum giganteum L.) in Antigen-Induced Arthritis
}

\author{
Mirian Farinon ${ }^{1,4}$, Priscila Schmidt Lora ${ }^{1,2}$, Leandro Nicolodi Francescato ${ }^{3}$, Valquiria Linck Bassani ${ }^{3}$, \\ Amélia Teresinha Henriques ${ }^{3}$, Ricardo Machado Xavier ${ }^{1,2}$ and Patricia Gnieslaw de Oliveira ${ }^{*}, 1,2$
}

\author{
${ }^{I}$ Serviço de Reumatologia, Hospital de Clínicas de Porto Alegre, Rua Ramiro Barcelos, 2350 - CEP 90035-903, Bairro \\ Rio Branco, Porto Alegre/RS, Brazil \\ ${ }^{2}$ Faculdade de Medicina, Universidade Federal do Rio Grande do Sul, Rua Ramiro Barcelos, 2400 - CEP 90035-003, \\ Bairro Santa Cecilia, Porto Alegre/RS, Brazil \\ ${ }^{3}$ Departamento de Produção de Matéria-Prima, Faculdade de Farmácia, Universidade Federal do Rio Grande do Sul, \\ Avenida Ipiranga, 2752 - CEP 90610-000, Bairro Santana, Porto Alegre/RS, Brazil \\ ${ }^{4}$ Instituto de Ciências Básicas da Saúde, Universidade Federal do Rio Grande do Sul, Rua Sarmento Leite, 500 - CEP \\ 90010-170, Bairro Centro, Porto Alegre/RS, Brazil
}

\begin{abstract}
Equisetum giganteum is a plant used in traditional medicine as diuretic. From our knowledge this is the first time this plant is tested in an in vivo model of acute inflammation. To evaluate the effect of aqueous extract of giant horsetail (AEGH) as immunomodulatory therapy, antigen-induced arthritis (AIA) was generated in mice with methylated bovine serum albumin (mBSA). Inflammation was evaluated by articular nociception, leukocytes migration and lymphocyte proliferation. AEGH reduced nociception at 3,6 and $24 \mathrm{~h}(\mathrm{P}<0.01)$, decreased leukocyte migration $(\mathrm{P}<$ 0.015), and inhibited lymphocyte proliferation stimulated with Concanavalin A and Lipopolysaccharide $(\mathrm{P}<0.05)$. In conclusion, AEGH has an anti-inflammatory potential in acute model of inflammation, as well as immunomodulatory effect on both B and T lymphocytes, with an action independent of cytotoxicity.
\end{abstract}

Keywords: Equisetum giganteum L., aqueous extract of giant horsetail (AEGH), Antigen-Induced Arthritis (AIA), immunomodulatory therapy.

\section{INTRODUCTION}

Rheumatoid arthritis (RA) is a chronic inflammatory joint disease characterized by inflammation of the synovium that leads to destruction of cartilage and bone [1]. Despite the significant progress in treatment strategies and new therapeutics for RA [2], significant limitations as well as side effects are found in their efficacy [3]. Thus, there is a great interest in studying new therapies.

Equisetum giganteum L., also known as "cavalinha", "cola de caballo" or "giant horsetail", is a native plant of Central and South America. Methods for the preparation of this species, mainly decoction and infusion, are widely used in traditional medicine as diuretic, hemostatic, urinary disorders, inflammatory conditions [4-7] and rheumatic diseases [8], among other applications. E. giganteum constitution includes flavonoids, styrylpyrones glycosides, hydroxycinnamic acid derivatives [9], metals, silica [10] and some apolar compounds in their oleoresin, as alkanes, fatty acids, methyl esters and steroid triterpenes [11].

*Address correspondence to this author at the Hospital de Clínicas de Porto Alegre, Serviço de Reumatologia, Rua Ramiro Barcellos, 2350, sala 645, Zip code 90035-003 - Porto Alegre, Brazil; Tel: +55-51-33598837; Fax: +55-51-33598340; E-mail: patty.go@gmail.com
Pharmacological studies revealed that the extracts of $E$. giganteum present antimicrobial effects [12], diuretic activity $[4,6]$ and no oral acute toxicity in mice [5]. Other Equisetum species have shown to present antioxidant, antinociceptive and anti-inflammatory activities [12,13]. These data together with the experience in traditional uses indicate the possibility of employing E. giganteum for the treatment of inflammatory diseases.

Antigen-induced arthritis (AIA) is a T-cell dependent immunological model in mice. Similar to other in vivo model of arthritis, AIA shows mimics with human rheumatoid arthritis [14]. As a consequence, this animal model may represent an excellent in vivo model for preclinical testing of new potential therapies RA and other inflammatory diseases. The aim of this study was to evaluate the effect of aqueous extract of E. giganteum as an immunomodulatory therapy.

\section{MATERIALS AND METHODOLOGY}

\section{Animals}

Male BALB/c wild-type mice (8-12 weeks, 20-25 g) were maintained in temperature-controlled rooms and were given water and food ad libitum. All experimental procedures involving animals were performed in accordance 
with the National Institutes of Health Guide for Care and Use of Animals and with the approval of our institutional ethics committee under number 120004.

\section{Preparation of Aqueous Extract}

The E. giganteum stems collected in May of 2011, in Santo Antônio da Patrulha, Rio Grande do Sul, Brazil (S $29^{\circ}$ $\left.52.374^{\prime}, \mathrm{W} 50^{\circ} 25.265^{\prime}, 12 \mathrm{~m}\right)$ were air-dried and grounded in a hammer mill. The plant authenticity was evaluated and the voucher specimen (number 88339) was deposited in the Herbarium at the Fundação Zoobotânica do Rio Grande do Sul (Porto Alegre, RS, Brazil). A decoction (plant: solvent ratio of $1: 11.7,95^{\circ} \mathrm{C}$ for $15 \mathrm{~min}$ ) was prepared and filtered after cooled. The decoct was spray-dried using a Niro Production Minor atomizer (GEA, Copenhagen, Denmark).

The AEGH was prepared under decoction based on the traditional use of the plant and the good yield of the extraction process. Aqueous extractive solution obtained was then spray-dried. The resulting dried extract (AEGH) was used for the pharmacological tests. The chemical profile of the AEGH was not assessed in this study. However, the chemical and physicochemical profile of the plant has been previously established by our group [9], where we can verify high content of silica and minerals, as well as the presence of caffeic acid derivatives, flavonoids and styrylpyrones.

\section{Induction of AIA}

AIA was induced according to Grespan et al. (2008) [16]. Fourteen BALB/c mice were sensitized by subcutaneous (s.c.) injected with $500 \mu \mathrm{g}$ of mBSA (Sigma Aldrich, St. Louis/EUA) dissolved in $0.2 \mathrm{ml}$ of an emulsion containing $0.1 \mathrm{ml}$ of $0.9 \%$ saline and $0.1 \mathrm{ml}$ of complete Freund's adjuvant (Sigma Aldrich, St. Louis/USA) administered on day 0 . Booster injections were administered for almost 2 weeks (7-14 days) using incomplete Freund's adjuvant (Sigma Aldrich, St. Louis/USA). Treatment started at day 19 and mice received AEGH $(600 \mathrm{mg} / \mathrm{kg})$ or vehicle ( $0.9 \%$ saline) orally in $100 \mu \mathrm{l}$, twice a day. On day 21 , arthritis was induced in pre-immunized animals by intraarticular (i.a.) injection with $30 \mu \mathrm{g}$ of mBSA dissolved in 10 $\mu l$ of saline into the left tibiofemoral joint. As a negative control $10 \mu \mathrm{l}$ of saline without mBSA was injected into the right tibiofemoral joint (contralateral joint) of vehicle group, consisting in the saline group.

\section{Evaluation of Articular Nociception}

Articular nociception was evaluated on $0,1,3,6$ and $24 \mathrm{~h}$ after i.a. injection of mBSA according to Oliveira et al. (2011) [17]. Mice were placed in a quiet room in acrylic cages with a wire-grid floor for 15-30 minutes before testing for environmental adaptation. An electronic pressure meter was used, consisting of a hand-held force transducer fitted with a polypropylene tip (Insight Instruments, Ribeirão Preto, São Paulo/BR). An increasing perpendicular force was applied to the central area of the plantar surface of the hind paw to induce flexion of the tibiofemoral joint, followed by paw withdrawal. The electronic pressure meter automatically recorded the intensity of the force applied when the paw was withdrawn, with results expressed as the flexion-elicited withdrawal threshold in grams $(\mathrm{g})$.

\section{Evaluation of In Vivo Total Leucocytes Migration}

After death, articular cavities of mice were washed twice with $5 \mu \mathrm{l}$ phosphate buffered saline $(0.15 \mathrm{M} \mathrm{NaCL}, 6.5 \mathrm{mM}$ phosphate and $1 \mathrm{mM}$ EDTA) in a final volume of $100 \mu \mathrm{l}$ to evaluate leukocyte migration at $24 \mathrm{~h}$ after i.a. injection of mBSA. The total number of leukocytes was determined in a Neubauer chamber under optical microscopy.

\section{Cell Viability Assay}

Cell viability was determined by MTT [3-(4,5dimethylthiazol-2-yl)-2,5-diphenyl-2H tetrazolium bromide] assay [18]. Lymphocytes from non-sensitized BALB/c lymph nodes were removed aseptically and cultured in triplicate $\left(5 \times 10^{5}\right.$ cells/well - 96 -well plate) for $48 \mathrm{~h}$ at $37^{\circ} \mathrm{C}$ in $5 \% \mathrm{CO}_{2}$ in RPMI medium, treated or not with AEGH (20, 40 and $80 \mu \mathrm{g} / \mathrm{ml})$. Twenty microliters of MTT $(0.5 \mathrm{mg} / \mathrm{ml})$ was added in each well and after $4 \mathrm{~h}$ of incubation the supernatants were removed and $100 \mu \mathrm{l}$ of DMSO (Sigma Aldrich, St. Louis/EUA) was added to dissolve the MTT formazan crystals. After shaking the plate, the absorbance of each well was read at $570 \mathrm{~nm}$.

\section{Lymphocyte Proliferation Assay}

Lymphocyte proliferation assay was performed using MTT assay [18]. Lymph nodes of non-sensitized BALB/c were removed aseptically. Lymphocytes were extracted, plated and cultured in triplicate $\left(5 \times 10^{5}\right.$ cells/well in a 96well plate) for $48 \mathrm{~h}$ at $37^{\circ} \mathrm{C}$ in $5 \% \mathrm{CO}_{2}$ with RPMI medium stimulated with concanavalin A (ConA) $(5 \mu \mathrm{g} / \mathrm{ml})$ or lipopolysaccharide (LPS) $(10 \mu \mathrm{g} / \mathrm{ml})$ and treated or not with AEGH $(80 \mu \mathrm{g} / \mathrm{ml})$. Twenty microliters of MTT $(0.5 \mathrm{mg} / \mathrm{ml})$ was added in each well and after $4 \mathrm{~h}$ of incubation the supernatants were removed and $100 \mu \mathrm{l}$ of DMSO (Sigma Aldrich, St. Louis/EUA) was added to dissolve the MTT formazan crystals. After shaking the plate, the absorbance of each well was read at $570 \mathrm{~nm}$.

\section{Statistical Analysis}

Data are presented as mean \pm SEM. Groups were compared by the analysis of variance with Tukey's adjustment for multiple comparisons or by Student's t-test using GraphPad Prism 5.0. Statistical differences were considered to be significant when $\mathrm{P}<0.05$.

\section{RESULTS}

\section{Treatment with AEGH Reduced Inflammatory Para- meters of Acute AIA}

In AIA model, mBSA injection into tibiofemoral joint of immunized mice induces inflammation which causes significant increased nociception and leukocyte migration 
into the articular cavity, as compared to the negative control contralateral joint in the same mice [17].

Nociception (Fig. 1A) was first noted $1 \mathrm{~h}$ after the antigenic challenge and became more intense in $3 \mathrm{~h}$ and $6 \mathrm{~h}$, then remaining relatively stable till $24 \mathrm{~h}$. Treatment with AEGH significantly reduced nociception on 3,6 and $24 \mathrm{~h}(\mathrm{P}$ $<0.01)$.
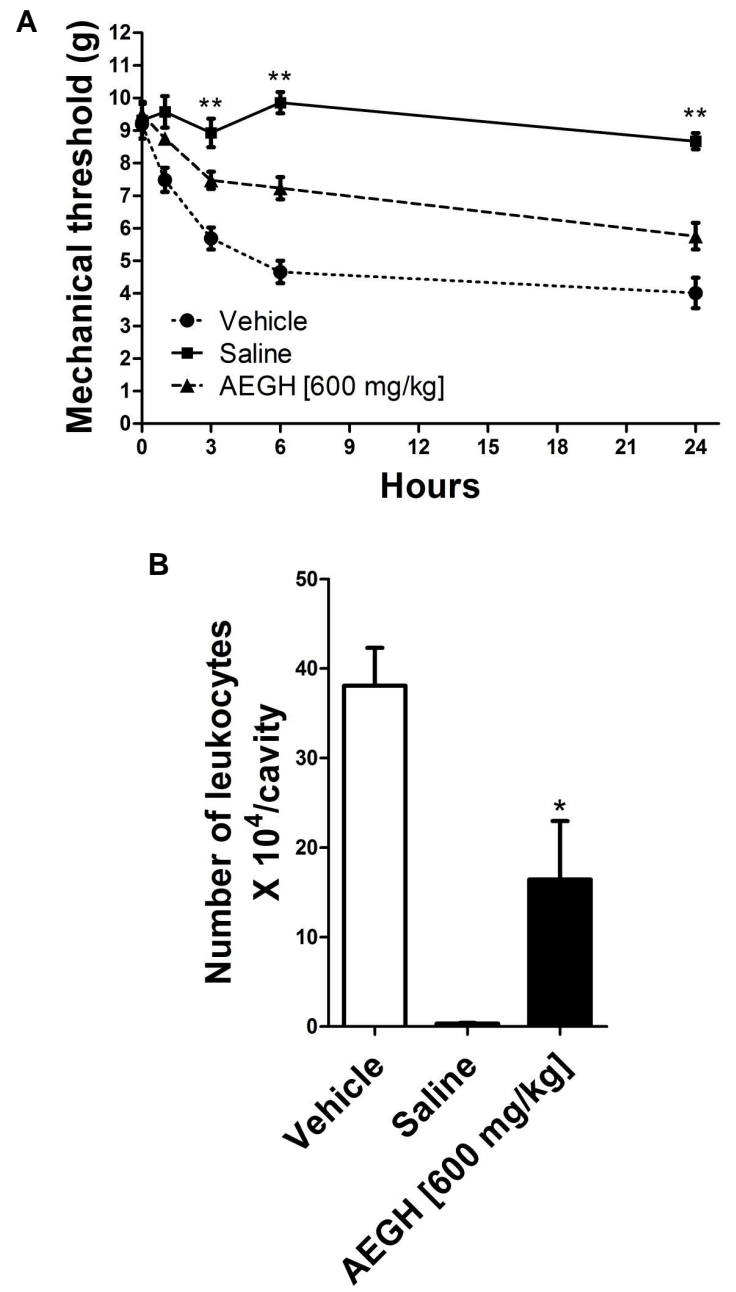

Fig. (1). In vivo experiments. (A) Nociception, evaluated at 0, 1, 3, 6 and 24 hours after i.a. injection. Each bars represents mean \pm $\operatorname{SEM}(\mathrm{n}=7) .{ }^{*} \mathrm{P}<0.05$ on time $1,{ }^{* *} \mathrm{P}<0.01$ on times 3,6 and $24 \mathrm{~h}$ versus vehicle treatment, by two-way analysis of variance (ANOVA) followed by the Tukey's post hoc test. (B). Leucocyte migration into the articular cavity of the knee joint, assessed 48 hours after treatment with vehicle or AEGH $[600 \mathrm{mg} / \mathrm{kg}$ orally, twice a day]. Injection of saline alone was used as negative control. Each bar represents mean \pm SEM $(n=7) . * P=0.015$ versus vehicle treatment, by Student's unpaired t-test.

Leukocyte infiltration triggered by i.a. injection plays an essential role in this experimental model and contributes to the articular damage [16], being an important marker of local inflammatory activity. Treatment with AEGH significantly reduced leukocyte recruitment $(43.13 \%)$ to the site of inflammation (16.42 $\pm 6.54 \times 10^{4}$ leukocytes/cavity) as compared with vehicle $\left(38.07 \pm 4.24 \times 10^{4}\right.$ leukocytes/cavity) $(\mathrm{P}<0.015)$ (Fig. 1B).

\section{AEGH Inhibited In Vitro Lymphoproliferation}

Lymphocytes proliferation was induced with ConA, which present nonspecific action, stimulating both $\mathrm{T}$ and $\mathrm{B}$ lymphocytes, and with LPS, that acts primarily on B lymphocytes, via B Cell Receptor and Toll-like 4 Receptor. AEGH inhibited lymphoproliferation induced by both mitogens in $23.56 \%$ and $31.77 \%$, respectively $(\mathrm{P}<0.05)$ (Fig. 2B, C).

Inaddition, AEGH showed no cytotoxicity on lymphocytes (Fig. 2A) at the treatment doses, maintaining cells viability similar to the unexposed control cells.

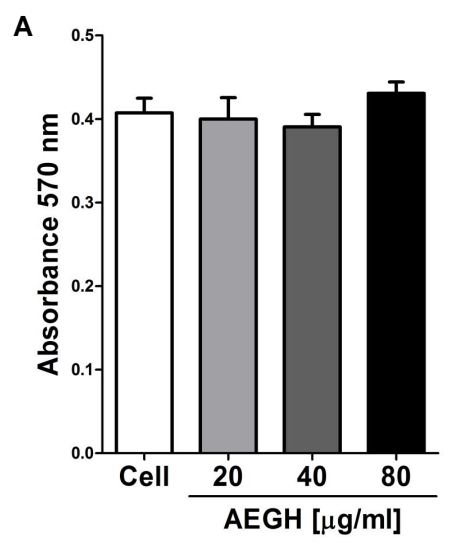

B

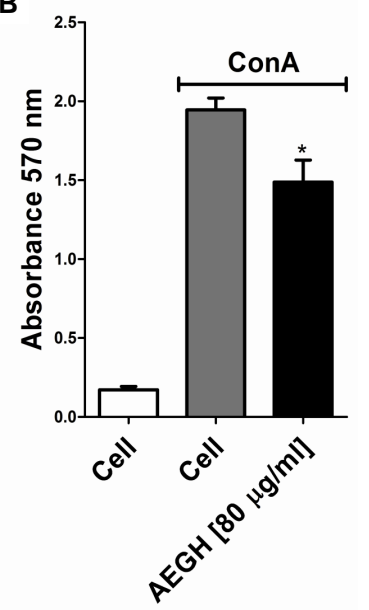

C

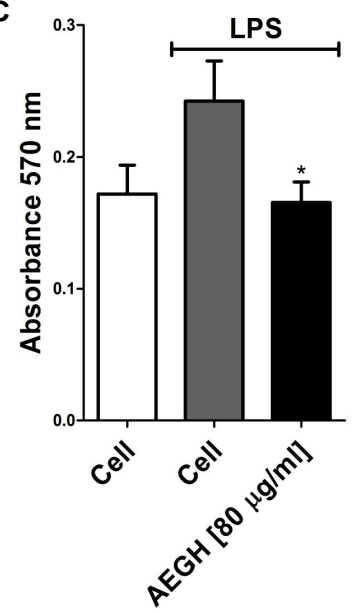

Fig. (2). In vitro assay. (A) Effect of AEGH on lymphocyte cell viability. Lymphocytes were incubated with AEGH at indicated concentrations for $48 \mathrm{~h}$. Each bar represents mean \pm SEM. Treatment with AEGH did not affect cell viability. (B) Effect of AEGH on lymphocyte proliferation induced by ConA [5 $\mu \mathrm{g} / \mathrm{ml}]$ and treated with or without AEGH $[80 \mu \mathrm{g} / \mathrm{ml}]$ for $48 \mathrm{~h}$. Each bar represents mean \pm SEM $(n=6)$. Cells incubated only with RPMI medium were used as unstimulated controls. $* \mathrm{P}<0.05$ versus ConA stimulated but non-treated cells, by Student's unpaired t-test. (C). Effect of AEGH on lymphocyte proliferation induced by LPS. Lymphocytes were incubated with LPS $[10 \mu \mathrm{g} / \mathrm{ml}]$ and treated with or without AEGH $[80 \mu \mathrm{g} / \mathrm{ml}]$ for $48 \mathrm{~h}$. Each bars represents mean \pm SEM $(\mathrm{n}=6)$. Cells incubated only with RPMI medium was used as unstimulated control. ${ }^{*} \mathrm{P}<0.05$ versus LPS stimulated but nontreated cells, by Student's unpaired t-test. 


\section{DISCUSSION}

In order to evaluate the effect of AEGH on inflammation we chose an arthritis immunomediated $\mathrm{T}$ cell-dependent model. This model produces an acute inflammation and similar pathological aspects of RA [15]. In this model, the i.a. injection of mBSA induces accentuated migration of leucocytes after $6 \mathrm{~h}$, with a highest influx on $24 \mathrm{~h}$ [16]. Additionally, the inflammatory process with cell influx and circulation of proinflammatory cytokines such as interleukin (IL)-6, IL-1 $\beta$, IL-2 and interferon $\gamma$ generate accentuated nociception.

In our study, treatment with AEGH markedly reduced nociception induced by AIA. This finding corroborates with the study of Do Monte et. al. (2004) [14], where treatments with hydroalcoholic extract of $E$. arvense reduced nociception in mouse experimental models of abdominal constriction and formalin-injected paw. Also, leukocytes migration locally was reduced with treatment. This finding confirms again the study of Do Monte et al. (2004) [14], where treatment with hydroalcoholic extract of $E$. arvense reduced mice paw edema caused by injection of carrageenan.

Regarding the pharmacological activity, previous studies have shown that Equisetum species presents antioxidant, antinociceptive and anti-inflammatory activities [12, 14], however this is the first study to evaluate the antiinflammatory effect of this specie (E. giganteum) on a model of arthritis and on lymphocytes in vitro. Our results agree with the previously reported anti-inflammatory and antinociceptive effects of flavonoids [19], the major secondary metabolites present in E. giganteum [9]. One of the important mechanisms of flavonoids in these processes can be an inhibition of eicosanoid generating enzymes including phospholipase A2, cyclooxygenases, and lipoxygenases, thereby reducing the concentrations of prostanoids and leukotrienes [20]. For other compounds, such as styrylpyrones and hydroxycinnamic acid derivatives, antioxidant $[21,22]$ and $\mathrm{NF}-\kappa \mathrm{B}$ inhibitory activity $[23,24]$ have been reported.

In conclusion, our study shows that AEGH has an interesting anti-inflammatory potential in an acute model of inflammation, as well as immunomodulatory effect on both $\mathrm{B}$ and $\mathrm{T}$ lymphocytes, with an action independent of cytotoxicity. Further studies are needed to better explore the immuno-inflammatory pathways affected by AEGH, as well as its potential clinical use.

\section{CONFLICT OF INTEREST}

The authors declare that this article content has no conflict of interest.

\section{ACKNOWLEDGEMENTS}

This research was supported by the Coordenação de Aperfeiçoamento de Pessoal de Nível Superior (CAPES) and Fundo de Incentivo a Pesquisa do Hospital de Clínicas de Porto Alegre (FIPE-HCPA).

\section{REFERENCES}

[1] Scott DL, Wolfe F, Huizinga TW. Rheumatoid arthritis. Lancet 2010; 376: 1094-108.

[2] Smolen JS, Steiner G. Therapeutic strategies for rheumatoid arthritis. Nat Rev Drug Discov 2003; 2: 473-88.

[3] Doran MF, Crowson CS, Pond GR, O'Fallon WM, Gabriel SE. Predictors of infection in rheumatoid arthritis. Arthritis Rheum 2002; 46: 2294-300.

[4] Leal DP, Isla MI, Vattuone MA, Sampietro AR. A hysteretic invertase from Equisetum giganteum L. Phytochemistry 1999; 52: 1009-16.

[5] Cáceres A, Girón LM, Martínez AM. Diuretic activity of plants used for the treatment of urinary ailments in Guatemala. J Ethnopharmacol 1987; 19: 233-45.

[6] Pérez Gutiérrez RM, Laguna GY, Walkowski A. Diuretic activity of Mexican equisetum. J Ethnopharmacol 1985; 14: 269-72.

[7] Gorzalczany S, Rojo A, Rondina RVD, Debenedetti SL, Acevedo MCD. Estudio de toxicidade aguda por via oral de plantas medicinais argentinas. Acta Farm Bonaerense 1999; 18: 221-4.

[8] Vendruscolo GS, Simões CMO, Mentz L. Etnobotanica do Rio Grande do Sul: Análise comparativa entre o conhecimento original e atual sobre plantas medicinais nativas. Pesquisa botânica, São Leopoldo: Instituto Anchietano de Pesquisas 2005; 56: 585-320.

[9] Francescato LN, Debenedetti SL, Schwanz TG, Bassani VL, Henriques AT. Identification of phenolic compounds in Equisetum giganteum by LC-ESI-MS/MS and a new approach to total flavonoid quantification. Talanta 2013; 105: 192-203.

[10] Ovalles J, Fuller J, Spinetti M. Metals, silica and ahs content of Equisetum bogotense H.B.K. and Equisetum giganteum L.(Horsetail). Rev Fac de Farm 1996; 32: 2-4.

[11] Michielin EMZ, Bresciani LFV, Danielski L, Yunes RA, Ferreira SRS. Composition profile f horsetail (Equisetum giganteum L.) oleoresin: comparing SFE and organic solvents extraction. J Supercrit Fluids 2005; 33: 131-8.

[12] Kloucek P, Polesny Z, Svobodova B, Vlkova E, Kokoska L. Antibacterial screening of some Peruvian medicinal plants used in Callería District. J Ethnopharmacol 2005; 99: 309-12.

[13] Stajner D, Popović BM, Canadanović-Brunet J, Anackov G. Exploring Equisetum arvense L., Equisetum ramosissimum L. and Equisetum telmateia L. as sources of natural antioxidants. Phytother Res 2009; 23: 546-50.

[14] Do Monte FH, dos Santos JG, Russi M, Lanziotti VM, Leal LK, Cunha GM. Antinociceptive and anti-inflammatory properties of the hydroalcoholic extract of stems from Equisetum arvense L. in mice. Pharmacol Res 2004; 49: 239-43.

[15] Ferraccioli G, Bracci-Laudiero L, Alivernini S, Gremese E, Tolusso B, De Benedetti F. Interleukin-1 $\beta$ and interleukin-6 in arthritis animal models: roles in the early phase of transition from acute to chronic inflammation and relevance for human rheumatoid arthritis. Mol Med 2010; 16:552-7.

[16] Grespan R, Fukada SY, Lemos HP, et al. CXCR2-specific chemokines mediate leukotriene B4-dependent recruitment of neutrophils to inflamed joints in mice with antigen-induced arthritis. Arthritis Rheum 2008; 58: 2030-40.

[17] Oliveira PG, Grespan R, Pinto LG, Meurer L, Brenol JC, Roesler $\mathrm{R}$, et al. Protective effect of RC-3095, an antagonist of the gastrinreleasing peptide receptor, in experimental arthritis. Arthritis Rheum 2011; 63: 2956-65.

[18] Mosmann T. Rapid colorimetric assay for cellular growth and survival: application to proliferation and cytotoxicity assays. J Immunol Methods 1983; 65: 55-63.

[19] De Melo GO, Malvar DoC, Vanderlinde FA, Rocha FF, Pires PA, Costa EA, et al. Antinociceptive and anti-inflammatory kaempferol glycosides from Sedum dendroideum. J Ethnopharmacol 2009; 124: 228-32.

[20] Kim HP, Son KH, Chang HW, Kang SS. Anti-inflammatory plant flavonoids and cellular action mechanisms. J Pharmacol Sci 2004; 96: 229-45

[21] Jung JY, Lee IK, Seok SJ, Lee HJ, Kim YH, Yun BS. Antioxidant polyphenols from the mycelial culture of the medicinal fungi Inonotus xeranticus and Phellinus linteus. J Appl Microbiol 2008; 104: $1824-32$. 
[22] Maurya DK, Devasagayam TP. Antioxidant and prooxidant nature of hydroxycinnamic acid derivatives ferulic and caffeic acids. Food Chem Toxicol 2010; 48: 3369-73.

[23] Wu CS, Lin ZM, Wang LN, et al. Phenolic compounds with NF$\kappa \mathrm{B}$ inhibitory effects from the fungus Phellinus baumii. Bioorg Med Chem Lett 2011; 21: 3261-7.
[24] Nagasaka R, Chotimarkorn C, Shafiqul IM, Hori M, Ozaki H, Ushio H. Anti-inflammatory effects of hydroxycinnamic acid derivatives. Biochem Biophys Res Commun 2007; 358: 615-9.

(C) Farinon et al.; Licensee Bentham Open.

This is an open access article licensed under the terms of the Creative Commons Attribution Non-Commercial License (http://creativecommons.org/licenses/by-nc/ $3.0 /$ ) which permits unrestricted, non-commercial use, distribution and reproduction in any medium, provided the work is properly cited. 